\title{
TITLE: Effect of lactic acid bacteria on mercury toxicokinetics
}

AUTHORS: Carlos Jadán-Piedra, Álvaro Crespo, Vicente Monedero, Dinoraz Vélez, Vicenta Devesa, Manuel Zúñiga

ADDRESS: Instituto de Agroquímica y Tecnología de Alimentos (IATA-CSIC), C/ Agustín Escardino 7, 46980 - Paterna (Valencia), Spain.

CORRESPONDING AUTHOR: Manuel Zúñiga; telephone (+34) 963900 022; fax (+34) 963636 301; e-mail: btcman@iata.csic.es)

\begin{abstract}
The capacity of two LAB strains to inhibit inorganic $[\mathrm{Hg}(\mathrm{II})]$ and organic (methyl- $\mathrm{Hg}$; $\mathrm{MeHg}$ ) mercury translocation through monolayers of co-cultures of NCM460 and HT29-MTX colonic cells was evaluated. Lactobacillus casei BL23 and Lactobacillus acidophilus ATCC4356 reduced the permeability of $\mathrm{Hg}(\mathrm{II})$ and $\mathrm{MeHg}$ from aqueous solutions through NCM460/HT29-MTX monolayers (20 to 94\% reduction). However, assays using the bioaccessible (soluble) $\mathrm{Hg}$ fraction obtained by in vitro gastrointestinal digestion of $\mathrm{Hg}$-contaminated swordfish only showed a reduction (42\%) with the BL23 strain. In vivo experiments carried out in mice receiving an acute dose of $\mathrm{Hg}$ (II) or $\mathrm{MeHg}(0.5 \mathrm{mg} / \mathrm{kg}$ body weight/day) with or without lactobacilli resulted in significant decreases of the bioavailability of $\mathrm{MeHg}$ with both strains and increased excretion of $\mathrm{Hg}$ in feces after treatment with the lactobacilli. However, $\mathrm{Hg}$ (II) bioavailability or excretion was not affected. $\mathrm{Hg}$ accumulation in liver and kidney remained similar in LAB-treated or non-treated animals. This is the first study of the impact of LAB on $\mathrm{Hg}(\mathrm{II})$ and $\mathrm{MeHg}$ toxicokinetics and shows that some LAB strains have potential to diminish MeHg bioavailabiliy. Furthermore, it has established the basis for new studies
\end{abstract}


on the protective effect of LAB under conditions resembling subchronic and chronic $\mathrm{Hg}$ exposures.

Keywords: Mercury, Lactobacillus, bioavailability, NCM460, HT29-MTX, mouse.

\section{Highlights}

Lactobacillus strains decreased $\mathrm{Hg}$ permeability in NCM460/HT29-MTX cell monolayers.

Lactobacillus casei BL23 decreased methylmercury bioavailability in acutely exposed mice.

Mercury accumulation in liver and kidney was not affected by Lactobacillus supplementation.

\section{ABBREVIATIONS}

AUC: area under the curve

CFU: colony forming units

DMEM: Dulbecco’s modified Eagle's medium

EFSA: European Food Safety Authority

FBS: fetal bovine serum

HBSS: Hank's balanced salt solution

HEPES: N-2-hydroxyethylpiperazine-N'-2-ethanesulfonic acid

LAB: lactic acid bacteria

LY: Lucifer yellow

MeHg: methylmercury

PBS: phosphate-buffered saline

TEER: transepithelial electric resistance 


\section{Introduction}

Mercury $(\mathrm{Hg})$ is a toxic trace element whose presence in nature is mainly due to anthropogenic causes. A large part of the world population is exposed to $\mathrm{Hg}$ through food, where it is mostly found as divalent inorganic $\mathrm{Hg}[\mathrm{Hg}(\mathrm{II})]$ or methylmercury (MeHg). The toxic effects of $\mathrm{Hg}$ are well known; the critical target for the toxicity of inorganic $\mathrm{Hg}$ is the kidney, and it also produces toxic effects on the liver, and nervous, immune and reproductive systems (EFSA, 2012). MeHg causes adult and developmental neurotoxicity (EFSA, 2012) and is also classified by the International Agency for Research on Cancer as possibly carcinogenic for humans (IARC, 1993).

Environmental $\mathrm{Hg}$ exposure, mainly due to mining activities, affects populations in Africa, Asia and Latin America. For example, $\mathrm{Hg}$ contents in biomarkers exceeds the reference values in more than $70 \%$ of individuals in populations of the Colombian, Brazilian and Peruvian Amazonia (Ashe, 2012; Malm, 1998; Olivero-Verbel et al., 2016). In countries where environmental $\mathrm{Hg}$ contamination is negligible, dietary $\mathrm{Hg}$ exposure can also exceed the recommended limits. A study conducted in Spain revealed a large proportion of newborns with cord blood $\mathrm{Hg}$ concentrations above the limit proposed by the U.S. Environmental Protection Agency $(5.8 \mu \mathrm{g} / \mathrm{L}$ for $\mathrm{MeHg}$ ), due mainly to oily fish consumption by their mothers during pregnancy (Ramon et al., 2011). The last report of the European Food Safety Authority (EFSA) shows that the mean dietary exposure exceeds the tolerable weekly intake (TWI) for $\mathrm{MeHg}$ in toddlers and other children in some surveys and the $95^{\text {th }}$ percentile dietary exposure is close to or above the TWI for all age groups (EFSA, 2012).

International organizations such as EFSA or the World Health Organization recommend reducing exposure to this element, especially for the most susceptible population groups (pregnant women and children). Health and food safety agencies from many countries 
have recommended limiting consumption of certain fish products, especially for these groups. However, due to the high nutritional value of some fish products, avoiding their consumption is not an adequate measure. Among many existing possibilities for reducing exposure, the reduction of the entry of the toxic element into the systemic circulation after ingestion (bioavailability) has been considered.

Certain strains of lactic acid bacteria (LAB), normal inhabitants of the gastrointestinal tract and commonly present in many fermented food products, possess an elevated ability to remove metals from aqueous solutions (Chiocchetti et al., 2018). Studies about the impact of LAB in cadmium $(\mathrm{Cd})$ or lead $(\mathrm{Pb})$ accumulation have been carried out in animal models with good results (Li et al., 2017; Yi et al., 2017; Zhai et al., 2013; Zhai et al., 2015).

Despite the evidence supporting the beneficial effects of LAB on the relief of the toxicity caused by some heavy metals, research about $\mathrm{Hg}$, and most specifically $\mathrm{MeHg}$, is scarce. A human intervention study in Tanzania showed that intake of milk fermented with Lactobacillus rhamnosus GR-1 by pregnant women had a protective effect against increases in $\mathrm{Hg}$ and arsenic in blood (Bisanz et al., 2014), although the exposure levels of the studied cohort were not relevant. Alcántara et al. (Alcántara et al., 2017) evidenced the biosorption of $\mathrm{Hg}(\mathrm{II})$ and $\mathrm{MeHg}$ on the surface of lactobacilli and it has been shown that lactobacilli-Hg complexation also occurs during a simulated gastrointestinal digestion (Jadán-Piedra et al., 2017), suggesting that these bacteria could be used as a strategy for diminishing $\mathrm{Hg}$ intestinal absorption. Oral gavage administration of Lactobacillus plantarum cells or Bacillus coagulans spores to rats reduced the burden caused by $\mathrm{Hg}(\mathrm{II})$ exposure (Majlesi et al., 2017). A recent study in mice in which a Lactobacillus reuteri strain was orally administered has also shown that this bacterium resulted in a diminished $\mathrm{Hg}$ (II) toxicity, protecting the animals from the 
$\mathrm{Hg}(\mathrm{II})$-triggered oxidative stress and inflammation by acting on the MAPK and NF- $\kappa \mathrm{B}$ pathways (Jiang et al., 2018).

On the basis of previous studies (Jadán-Piedra et al., 2017), we have selected two Lactobacillus strains that displayed a good retention of $\mathrm{Hg}(\mathrm{II})$ and $\mathrm{MeHg}$ on their surfaces. The goals of the present work are, first, to verify whether complexation of $\mathrm{Hg}(\mathrm{II})$ and $\mathrm{MeHg}$ by these $\mathrm{LAB}$ has an effect on $\mathrm{Hg}$ permeability in a model of human intestinal epithelium, and second, to test their efficacy in reducing the arrival of both mercurial forms to the systemic circulation after oral intake in a mice model.

\section{Materials and Methods}

2.1. Mercury species

The solutions of $\mathrm{Hg}(\mathrm{II})$ and $\mathrm{MeHg}$ were prepared by diluting commercial standards of $\mathrm{Hg}\left(\mathrm{NO}_{3}\right)_{2}(1 \mathrm{~g} / \mathrm{L}$, Merck$)$ and $\mathrm{CH}_{3} \mathrm{HgCl}(1 \mathrm{~g} / \mathrm{L}$, Alfa Aesar), respectively.

\subsection{Swordfish bioaccessible fraction}

Cooked swordfish was submitted to an in vitro gastrointestinal digestion following the procedure described by Jadán-Piedra et al. (Jadán-Piedra et al., 2016) The resulting bioaccessible fraction was heated before the transport assay for $10 \mathrm{~min}$ at $90{ }^{\circ} \mathrm{C}$ in order to inhibit digestive enzymes. To facilitate cell viability, glucose (final concentration 1 $\mathrm{g} / \mathrm{L}$, Sigma) was added and osmolarity was adjusted with $\mathrm{NaCl}$ (3 mM, Panreac) to 300 $\pm 30 \mathrm{mOsm} / \mathrm{kg}$, using a freezing point osmometer (Automatic Micro-Osmometer Type 15 Löser, Löser Messtechnik).

2.3. Strains and growth conditions. 
The LAB strains used were Lactobacillus acidophilus BL17 (American Type Strain Culture Collection - ATCC4356) and Lactobacillus casei BL23 (Mazé et al., 2010). These strains were selected on the basis of their capacity to bind $\mathrm{Hg}$ species in in vitro tests under emulated gastrointestinal conditions (Jadán-Piedra et al., 2017). Lactobacilli were routinely grown in de Man-Rogosa-Sharpe (MRS) broth (Difco) under static conditions at $30{ }^{\circ} \mathrm{C}$ (BL17) or $37{ }^{\circ} \mathrm{C}$ (BL23). Bacterial cells were harvested by centrifugation $(5500 \times g, 10 \mathrm{~min})$ and washed with phosphate-buffered saline (PBS). The bacterial pellets were resuspended in PBS and adjusted to different OD (optical density at $595 \mathrm{~nm}$ ) for subsequent assays.

2.4. In vitro studies on mercury intestinal permeability

\subsubsection{Cell culture}

The NCM460 cell line was obtained from Incell Corporation and it was used at passages 15 to 30. The HT29-MTX cell line was kindly provided by Dr. Técla Lesuffleur (Institut National de la Santé et de la Recherche Médicale, INSERM UMR S 938, Paris, France) and used between passages 16 and 24. Cells were maintained in Dulbecco's modified Eagle's medium (DMEM) containing $4.5 \mathrm{~g} / \mathrm{L}$ glucose and $0.6 \mathrm{~g} / \mathrm{L}$ glutamine. For NCM460 cells, DMEM was supplemented with $10 \%$ (v/v) fetal bovine serum (FBS), 10 mM HEPES (N-2-hydroxyethylpiperazine-N'-2-ethanesulfonic acid), $100 \mathrm{U} / \mathrm{mL}$ of penicillin, $0.1 \mathrm{mg} / \mathrm{mL}$ of streptomycin and $0.0025 \mathrm{mg} / \mathrm{L}$ of amphotericin $\mathrm{B}$ (NCM-DMEMc). HT29-MTX medium was supplemented with 10\% (v/v) FBS, 1 mM sodium pyruvate, $10 \mathrm{mM}$ HEPES, $100 \mathrm{U} / \mathrm{mL}$ of penicillin, $0.1 \mathrm{mg} / \mathrm{mL}$ of streptomycin and $0.0025 \mathrm{mg} / \mathrm{L}$ of amphotericin B (HT-DMEMc).

The cells were incubated at $37{ }^{\circ} \mathrm{C}$ in an atmosphere with $95 \%$ relative humidity and a $\mathrm{CO}_{2}$ flow of $5 \%$. The medium was changed every 3 days. When the cell monolayer 
reached $80 \%$ confluence, the cells were detached with a solution of trypsin $(0.5 \mathrm{~g} / \mathrm{L})$ and EDTA (ethylene diamine tetraacetic acid, $0.22 \mathrm{~g} / \mathrm{L}$ ) and reseeded at a density of 5-6 $\times$ $10^{4}$ cells $/ \mathrm{cm}^{2}$. All the reagents used were obtained from Hyclone.

\subsubsection{Cellular permeability assays}

The assays were performed in 12-well plates with polyester membrane inserts $(12 \mathrm{~mm}$ diameter, $0.4 \mu \mathrm{m}$ pore-size; Transwell ${ }^{\circledR}$, Corning). NCM460/HT29-MTX co-cultures were prepared at an $80 / 20$ proportion. This ratio was chosen on the basis of the habitual percentages of both cellular types in the intestine (Hilgendorf et al., 2000). The cells were seeded at an initial density of $7.5 \times 10^{4}$ cell $/ \mathrm{cm}^{2}$ in $0.5 \mathrm{~mL}$ of HT-DMEMc added to the apical (top) compartment. HT-DMEMc medium (1.5 mL) was added to the basolateral compartment (bottom). The cells were incubated at $37{ }^{\circ} \mathrm{C}$ under an atmosphere of $95 \%$ relative humidity and $5 \% \mathrm{CO}_{2}$ for ten days with medium changes every three days. During this time the development and confluence of the cellular monolayer was checked by measuring the transepithelial electric resistance (TEER) with a Millicell ${ }^{\circledR}$-ERS voltimeter (Millipore Corporation). The reference values for considering an adequately formed monolayer for the assays were $170-190 \mathrm{Ohms} \mathrm{cm}$.

For permeability assays, the cellular medium was withdrawn. Then, $0.5 \mathrm{~mL}$ of $\mathrm{Hg}(\mathrm{II})$ or MeHg standards $(0.5 \mu \mathrm{g} / \mathrm{mL})$ prepared in Hank's balanced salt solution with $\mathrm{NaHCO}_{3}$ (HBSS, Lonza) containing $10 \mathrm{mM}$ HEPES or $0.5 \mathrm{~mL}$ of the previously obtained bioaccessible fraction of swordfish (Section 2.2), were added to the apical compartment with or without the bacterial strains (final ODs ranging from 0.3 to 1.2). Lucifer yellow (LY; Sigma) was also added to the apical side at $100 \mu \mathrm{M}$, a concentration that does not interfere with Hg transport (Vázquez et al., 2015; Vázquez et al., 2014), as a marker of 
monolayer integrity. HBSS medium with $10 \mathrm{mM}$ HEPES $(1.5 \mathrm{~mL})$ was added to the basolateral compartment.

At different times (30, 60, 90 and 120 min for $\mathrm{Hg}$ standards; 30, 45, 60 and 75 min for bioaccesible fractions), $0.7 \mathrm{~mL}$-aliquots were collected from the basolateral compartment and replaced by an equal volume of fresh medium (HBSS with $10 \mathrm{mM}$ HEPES). Mercury was quantified in the aliquots by microwave oven-assisted digestion and cold vapor atomic fluorescence spectrometry following the procedure described by Jadán-Piedra et al. (Jadán-Piedra et al., 2016). The methodology exhibited a linear range of $0.01 \mathrm{ng} \mathrm{Hg} / \mathrm{mL}$ to $2 \mathrm{ng} \mathrm{Hg} / \mathrm{mL}$. The instrumental detection (LOD) and quantification (LOQ) limits were $0.003 \mathrm{ng} \mathrm{Hg} / \mathrm{mL}$ and $0.01 \mathrm{ng} \mathrm{Hg} / \mathrm{mL}$ respectively. Considering the sample mass $(0.03-0.5 \mathrm{~g})$ and the volume $(10 \mathrm{~mL})$ employed for tissue analysis, LOQ values ranged between 0.2 and $3 \mathrm{ng} \mathrm{Hg} / \mathrm{g}$. The mean recovery calculated at two levels of fortification of tissue homogenates was in the range of $92-110 \%$. The method allowed accurate analysis of the fish protein muscle certified reference material for trace metals DORM-3 (National Research Council of Canada, NRCC) (certified Hg concentration: $0.382 \pm 0.06 \mathrm{mg} / \mathrm{kg}$ ).

Apparent permeability coefficients were calculated as $\mathrm{P}_{\mathrm{app}}=(\mathrm{dC} / \mathrm{dt}) \times\left(\mathrm{V}_{\mathrm{r}} / \mathrm{AC}_{\mathrm{o}}\right)$, where $\mathrm{dC} / \mathrm{dt}$ is the flux $(\mu \mathrm{g} / \mathrm{s})$ determined by the linear slope of the equation describing the variation of $\mathrm{Hg}$ concentrations, corrected by the dilution, over time; $\mathrm{V}_{\mathrm{r}}$ is the volume of the basolateral compartment $(1.5 \mathrm{~mL})$; $\mathrm{A}$ is the cell monolayer surface $\left(1.12 \mathrm{~cm}^{2}\right)$ and $\mathrm{C}_{\mathrm{o}}$ is the initial concentration of $\mathrm{Hg}$ added to the apical compartment $(0.5 \mu \mathrm{g} / \mathrm{mL}$ for $\mathrm{Hg}(\mathrm{II})$ and $\mathrm{MeHg}$ standards).

LY in aliquots collected at different times from the basolateral compartments was measured using a microplate reader (POLARstar OPTIMA, BMG-Labtech) at $485 \mathrm{~nm}$ excitation wavelength and emission at $520 \mathrm{~nm} . \mathrm{P}_{\text {app }}$ for LY was calculated as described 
for $\mathrm{Hg}$. The assays were considered valid when $\mathrm{P}_{\text {app }}$ for $\mathrm{LY}$ was lower than $1 \times 10^{-5}$ $\mathrm{cm} / \mathrm{s}$.

\subsection{Mercury toxicokinetics in mice}

\subsubsection{Animals}

Forty-two 4-weeks BALB/c female mice were obtained from Charles River. The animals had a weight ranging from 20 to $25 \mathrm{~g}$ and during the study they were kept in controlled environmental conditions (cycles of $12 \mathrm{~h}$ of light and dark, room temperature of $22{ }^{\circ} \mathrm{C}$ and humidity of $75 \%$ ) at the facilities of the Animal Production Section from the University of Valencia. The mice were fed ad libitum with standard rodent maintenance feed. The protocols applied to the animals were designed in conformity with the Spanish regulations for the use of experimental animals (BOE, 2013) and were approved by the Ethical Committee for Use of Laboratory Animals of the University of Valencia and the Agriculture, Fisheries, and Food Council of the Generalitat Valenciana (Spain).

\subsubsection{Mice experiments}

Six groups of seven animals were housed separately. Four groups received a daily bacterial dose $\left(5 \times 10^{8} \mathrm{CFU}\right.$ in $50 \mu \mathrm{L}$ PBS $)$ by oral gavage for a total of eight days. Two groups were dosed with L. casei BL23 and two groups received L. acidophilus BL17. The remaining two groups (controls) were given $50 \mu \mathrm{L}$ of PBS by gavage. After the eight days (preconditioning), the mice started to receive daily a single dose $(0.5 \mathrm{mg} / \mathrm{kg}$ body weight) of $\mathrm{Hg}(\mathrm{II})$ (three groups; BL23, BL17 and control) or MeHg (three groups; BL23, BL17 and control) with or without the bacteria for three days. The $\mathrm{Hg}$ concentrations for dosing were chosen taking into account toxicological studies in mice, 
where a NOAEL (non-observed adverse effects level) of $0.93 \mathrm{mg} / \mathrm{kg}$ body weight/day is stablished for renal effects in animals exposed to $\mathrm{Hg}$ (II) by gavage for 14 days (NTP, 1993). For MeHg, mice studies show LOAELs (lowest observed adverse effect level) for neurotoxic effects at doses of $4 \mathrm{mg} / \mathrm{kg}$ body weight/day for 7 days and $0.6 \mathrm{mg} / \mathrm{kg}$ body weight/day for two-years exposure (NRC, 2000).

The relative bioavailability was determined after the first administration of the treatment bacteria/Hg. Blood samples $(\sim 100 \mu \mathrm{L})$ were collected by puncturing the submandibular venous sinus at different times $(0,60,300$ and 1440 min after dosing). Blood samples were recovered in heparin tubes (Microvette, Sarstedt) and centrifuged (1500 $\mathrm{g}$ for 5 min at $4{ }^{\circ} \mathrm{C}$ ) for plasma isolation. Relative bioavailability $(\mathrm{F} \%)$ was calculated as $\mathrm{F} \%=\left(\mathrm{AUC}_{\mathrm{a}} / \mathrm{AUC}_{\mathrm{r}}\right) \times 100$, where $\mathrm{AUC}$ corresponds to the area under the curve representing $\mathrm{Hg}$ plasma content $(\mu \mathrm{g} / \mathrm{mL})$ versus time (min). $\mathrm{AUC}_{\mathrm{a}}$ are the values from animals administered with $\mathrm{Hg}$ and $\mathrm{LAB}$, whereas $\mathrm{AUC}_{\mathrm{r}}$ are the values from control animal receiving only $\mathrm{Hg}(\mathrm{II})$ or $\mathrm{MeHg}$. Calculations were carried out with SigmaPlot v13.5.

Additionally, fresh fecal pellets were recovered from individual mice $24 \mathrm{~h}$ after each $\mathrm{Hg}$ dosing in order to determine $\mathrm{Hg}$ fecal excretion. At the end of the experiment, animals were anesthetized by inhalation of isoflurane and euthanized by cervical dislocation. Liver and kidneys were extracted and thoroughly washed with PBS for determining Hg tissular accumulation. Mercury quantification in samples (plasma, feces and organs) was performed using the protocol describe previously (section 2.4.2).

\subsection{Statistics}

The statistical analyses of results were performed by Student t-test or one-way ANOVA with multiple post hoc comparisons by Tukey HSD test (SigmaPlot v13.5). Differences 
were considered significant at $\mathrm{p}<0.05$. The calculation of the sample sizes for in vivo assays were carried out with GPower 3.1, with $\alpha=0.05$ and a statistical power (1- $\beta$ ) of 0.8 .

\section{RESULTS}

3.1. In vitro evaluation of the effect of lactic acid bacteria on $\mathrm{Hg}$ permeability

To assess the effect of the selected LAB strains on the intestinal permeability of $\mathrm{Hg}$ species we employed and in vitro model consisting in a co-culture of two intestinal epithelial cells: NCM460, an epithelial colonic cell line and the mucus producing cell line HT29-MTX. The treatments assayed in the present study had no effects on the integrity of the cell monolayers, whose permeability coefficients of LY were lower than $1 \times 10^{-5} \mathrm{~cm} / \mathrm{s}$. However, it was evidenced that addition of LAB to the media resulted in a significant reduction of LY permeability (15-25\% reduction; data not shown), indicating that these microorganisms could decrease the paracellular transport.

Table 1 shows the $\mathrm{P}_{\text {app }}$ for $\mathrm{Hg}$ (II) and $\mathrm{MeHg}$ in HBSS medium through co-cultures of NCM460/HT29-MTX cells (80/20 proportion) in the absence or presence of the two lactobacilli strains assayed. L. casei BL23 and L. acidophilus BL17 strains significantly reduced $\mathrm{Hg}(\mathrm{II})$ permeability (74-94\%) when applied at an OD of 0.3 . However, this cell density did not result in reduced permeability for $\mathrm{MeHg}$. Increasing the amount of bacteria to an OD of 0.6 did not modify permeability for $\mathrm{MeHg}$ and significant reductions (20-31\%) were only achieved at an OD of 1.2 (Table 1).

We also determined the $\mathrm{P}_{\mathrm{app}}$ of $\mathrm{Hg}$ present in the bioaccessible fraction of naturallycontaminated swordfish obtained after cooking and performing a simulated gastrointestinal digestion (Table 2). Previous $\mathrm{Hg}$ speciation studies evidenced that most of the metal present in swordfish corresponds to MeHg (Torres-Escribano et al., 2010). 
The cooked sample of swordfish presented a concentration of $3.6 \pm 0.3 \mathrm{mg} \mathrm{Hg} / \mathrm{kg}$. After application of the gastrointestinal digestion, the concentration of $\mathrm{Hg}$ in the bioaccesible fraction was $1.6 \pm 0.2 \mathrm{mg} / \mathrm{kg}$. The presence of the BL23 strain at an OD of 1.2 reduced by $43 \%$ the $\mathrm{P}_{\mathrm{app}}$ of $\mathrm{Hg}$, whereas no reduction was observed with BL17 strain.

\subsection{Effect of lactic acid bacteria on $\mathrm{Hg}$ toxicokinetics in vivo}

\subsubsection{Effect of lactic acid bacteria on $\mathrm{Hg}$ bioavailability}

The areas under the curve (AUC) for $\mathrm{Hg}$ of animals orally given $\mathrm{Hg}$ (II) or $\mathrm{MeHg}$ in the absence or presence of lactobacilli are depicted in Fig. 1. Administration of both lactobacilli to animals by gavage $\left(5 \times 10^{8} \mathrm{CFU}\right)$ did not affect the plasmatic contents of $\mathrm{Hg}(\mathrm{II})$, but it resulted in a significant reduction of the $\mathrm{MeHg}$ concentration. Relative bioavailabilities calculated by comparing the AUCs of the co-exposures (metal + LAB) with those of the controls only treated with $\mathrm{Hg}$ are shown in Table 3. Under the assayed conditions, bacteria reduced $\mathrm{MeHg}$ bioavailability (median: $39 \%$ ); however, $\mathrm{Hg}(\mathrm{II})$ bioavailability was not affected.

\subsubsection{Effect of lactic acid bacteria on $\mathrm{Hg}$ fecal excretion}

Figures $2 \mathrm{~A}$ and $2 \mathrm{~B}$ show the $\mathrm{Hg}$ fecal excretion of mice exposed to $\mathrm{Hg}(\mathrm{II})$ and $\mathrm{MeHg}$, respectively. The data evidenced that the treatment with $\mathrm{LAB}$ and later co-exposure with $\mathrm{Hg}$ (II) did not influence $\mathrm{Hg}$ excretion, with the exception of BL17 strain during the first day of exposure (increase in excretion of 16-270\%). This increase, however, was not reflected in $\mathrm{Hg}$ plasma concentrations, where no differences in LAB-treated and untreated animals was seen for $\mathrm{Hg}(\mathrm{II})$ (Table 3).

For $\mathrm{MeHg}$ a different situation was found, as the animals treated with both lactobacilli strains showed a significant increase in fecal elimination of $\mathrm{Hg}$ at the third day. The 
BL17 strain led to an increased $\mathrm{Hg}$ excretion compared to control animals that ranged between 38 and $106 \%$ (median 72\%). Similarly, an increase in $\mathrm{Hg}$ excretion through feces was observed for BL23 strain: 13-124\% increase; median 68\%.

\subsubsection{Effect of lactic acid bacteria on $\mathrm{Hg}$ tissular accumulation}

Accumulation of $\mathrm{Hg}$ in liver and kidney of mice after three days of exposure is shown in Figures $3 \mathrm{~A}$ and $3 \mathrm{~B}$, respectively. Considering the differences detected in plasma levels and fecal excretions between both $\mathrm{Hg}$ forms, it was expected that tissular accumulation was much higher for $\mathrm{MeHg}$ compared to $\mathrm{Hg}(\mathrm{II})$. The higher absorption of MeHg over $\mathrm{Hg}(\mathrm{II})$ has been previously observed (Sasser et al., 1978) due to its lipophilic character (Halbach, 1990). This was true for liver (medians: MeHg 2534

$\mathrm{ng} / \mathrm{g} ; \mathrm{Hg}(\mathrm{II}) 250 \mathrm{ng} / \mathrm{g}$ ) but not for kidney, where the differences in accumulation were not statistically significant between groups (medians: MeHg 3895 ng/g; $\mathrm{Hg}$ (II) 2364 ng/g). Furthermore, no differences were observed in accumulation between animals treated or untreated with both LAB strains.

\section{DISCUSSION}

Results reported here constitute the first effort in analyzing the capacity of LAB to reduce $\mathrm{Hg}$ transport across an intestinal epithelium exposed to a real contaminated food. The use of LAB strains for reducing metal exposure presents several advantages. First they are GRAS microorganisms that are normal inhabitants of the gastrointestinal tract; and second, they may display a protective effect that counteracts the toxicity (reduction in pro-oxidant response linked to metal exposure) associated to some metals, as evidenced in animal trials (Jiang et al., 2018; Majlesi et al., 2017; Tian et al., 2012; Zhai et al., 2015). In this study we have shown that certain LAB strains that were previously 
characterized by their capacity to bind $\mathrm{Hg}(\mathrm{II})$ and $\mathrm{MeHg}$ during a simulated gastrointestinal digestion (Jadán-Piedra et al., 2017), reduce the in vitro $\mathrm{Hg}$ translocation across intestinal cells (Table 1). A number of mechanisms may account for the observed reduction in the translocation of $\mathrm{Hg}$ but the mechanisms linked to this reduction are probably different for aqueous solution and swordfish-derived $\mathrm{Hg}$. Metal adsorption onto the bacterial surface, which renders the metal non available for transport through the cell monolayers, possibly explains this effect in aqueous solutions (Alcántara et al., 2017). A very recent study carried out with Lactobacillus rhamnosus GR-1 also showed that this strain was able to reduce translocation of $\mathrm{Cd}(\mathrm{II})$ and $\mathrm{Pb}(\mathrm{II})$ through a Caco-2 monolayer probably by sequestering them from solution (Daisley et al., 2018).

Jadán-Piedra et al. (Jadán-Piedra et al., 2017), however, showed that the capacity for capturing swordfish-derived $\mathrm{Hg}$ by L. casei BL23 strain was dramatically lowered compared to $\mathrm{Hg}$ present in aqueous solutions, suggesting that $\mathrm{Hg}$ sequestration by lactobacilli was impaired under these conditions. The observed lower transport through the cell monolayers is possibly related to a modulation of the epithelial permeability. In the present study, we showed that the bacterial presence reduced paracellular transport of the LY marker through the cell monolayer, indicating a bacterial regulation of the paracellular permeability. Previous studies have shown that the permeability of the epithelium is largely governed by the proteins that make up the intercellular junctions (Anderson and Van Itallie, 2009). Some LAB are capable of increasing the expression of these proteins, augmenting the barrier function and generating a less-permeable epithelium (Ulluwishewa et al., 2011). In fact, Jiang et al. (Jiang et al., 2018) evidenced that Lactobacillus brevis avoided the drop in expression of tight junction proteins that was shown after $\mathrm{Hg}(\mathrm{II})$ exposure in mice. Zhai et al. also observed different modes of 
protection by lactobacilli against $\mathrm{Cd}(\mathrm{II})$ toxic effects that go beyond the mere metal sequestration, and are the result of a reinforcement of the intestinal barrier (Zhai et al., 2016). The likely reduction in the paracellular translocation generated by the lactobacilli should not affect the transport of $\mathrm{Hg}$ salts in aqueous solution, whose paracellular transport is negligible (Vázquez et al., 2015; Vázquez et al., 2014). However, it can affect permeability of other $\mathrm{Hg}$ forms present in the bioaccessible fractions of swordfish, where the metal could be forming complexes with thiolated compounds (George et al., 2011; Harris et al., 2003).

Considering the in vitro permeability data obtained in this study, it was expected that animals treated with both $\mathrm{LAB}$ strains would present reductions in $\mathrm{Hg}(\mathrm{II})$ and $\mathrm{MeHg}$ bioavailability accompanied by an increased fecal excretion and lower concentrations at target organs (liver and kidney). The employed LAB strains diminished $\mathrm{MeHg}$ bioavailability and augmented its fecal excretion, but this had no effect in the $\mathrm{Hg}$ contents of the analyzed organs. Previous studies have proven the efficacy of Lactobacillus plantarum (Zhai et al., 2013) or Leuconostoc mesenteroides (Yi et al., 2017) strains reducing hepatic and renal accumulation of $\mathrm{Cd}$ and $\mathrm{Pb}$. Regarding $\mathrm{Hg}$, only two in vivo experiments involving $\mathrm{Hg}(\mathrm{II})$ and bacteria able to capture this metal have been previously reported, but information about $\mathrm{MeHg}$ is not available. Dosing of a strain of L. plantarum or Bacillus coagulans spores $\left(10^{9} \mathrm{CFU} / \mathrm{animal}\right)$ reduced $\mathrm{Hg}$ (II) tissue accumulation after 48 days of treatment in rats (Majlesi et al., 2017). In the recent study of Jiang et al. (Jiang et al., 2018), administration of a L. brevis strain $\left(10^{9}\right.$ CFU/animal) resulted in increased $\mathrm{Hg}$ fecal excretion after a single $\mathrm{Hg}$ (II) dose of 10 $\mathrm{mg} / \mathrm{Kg}$ body weight, and the accumulation of $\mathrm{Hg}$ in the muscles of mice was reduced. However, at the bacterial concentrations employed in our study $\left(5 \times 10^{8} \mathrm{CFU} / \mathrm{animal}\right)$, no significant effects were observed in $\mathrm{Hg}(\mathrm{II})$ toxicokinetics. This was true even if 
reduction in $\mathrm{P}_{\mathrm{app}}$ for $\mathrm{Hg}(\mathrm{II})$ by the bacteria in the in vitro experiments was more efficient compared to $\mathrm{MeHg}$.

The interactions that can take place between $\mathrm{Hg}$ and dosed lactobacilli at the lumen, the enterohepatic circulation and the presence of the intestinal microbiota, among other factors, could affect the capacity of the strains to bind the mercurial species or favor the release of the already bound $\mathrm{Hg}$, explaining the divergence between in vitro and in vivo experiments, especially for $\mathrm{Hg}(\mathrm{II})$. A recent study with in vitro cultures of human microbiota from two subjects has shown that $\mathrm{MeHg}$ demethylation occurred in a individual dependent manner and was influenced by nutrient availability (Guo et al., 2018). A similar situation has been previously observed for other metallic cations. Thus, Zhai et al. (Zhai et al., 2015) showed that certain LAB strains that were effective in reducing $\mathrm{Cd}(\mathrm{II})$ solubility in vitro, did not display an elevated capacity to modify the metal toxicokinetics in laboratory animals. Li et al. (Li et al., 2017) also evidenced that Lactobacillus bulgaricus KLDS1.0207, a strain able to capture $80 \%$ of $\mathrm{Pb}$ (II) present in aqueous solutions, did not modify substantially $\mathrm{Pb}$ hepatic and renal concentrations after two weeks of exposure to the bacteria followed by an acute $\mathrm{Pb}(\mathrm{II})$ exposition in mice. The observed differences in the protective effects of LAB on metal (and specifically $\mathrm{Hg}$ ) accumulation reported to date ( $\mathrm{Li}$ et al., 2017; Majlesi et al., 2017) suggest that strain-dependent modes of action, rodent strain, supplied diet, metal doses and duration of the treatments (acute, subchronic or chronic exposures) may significantly affect the efficacy of LAB as protective agents against metal toxicity and should be investigated.

The results obtained in this study evidence that strains of $L$. casei and L. plantarum could represent promising strategies for reducing $\mathrm{MeHg}$ bioavailability. It is worth mentioning that the major source for $\mathrm{Hg}$ exposure in humans is $\mathrm{MeHg}$ derived from 
seafood. The assays with cell cultures show that L. casei BL23 reduced Hg permeability from swordfish, but in vitro studies do not necessarily correlate with in vivo results. Therefore, it is necessary to test whether MeHg toxicokinetics is modified when $\mathrm{MeHg}$ is conveyed through food. Furthermore, more assays are necessary in order to confirm that $\mathrm{LAB}$-modulated $\mathrm{MeHg}$ bioavailability has an impact on $\mathrm{Hg}$ organ accumulation, especially under scenarios considering longer exposure times, lower doses and $\mathrm{Hg}$ vehicles approaching the actual conditions of exposure in humans.

\section{Acknowledgements}

This work was supported by the Spanish Ministry of Science, Universities and Innovation (AGL2015-68920-R). Carlos Jadán Piedra received a Personnel Training Grant from SENESCYT (Ecuadorian Ministry of Higher Education, Science, Technology and Innovation) to carry out this study. Álvaro Crespo had a Contrato de Garantía Juvenil from the Spanish Government which was partially funded by the European Social Fund. We thank Inmaculada Noguera, from the Animal Production Service from the University of Valencia, for her assistance in the animal experiments. 
Table 1. Effect of various lactic acid bacteria on the in vitro permeability of $\mathbf{H g}$ (II) and MeHg. Apparent permeability coefficients $\left(\mathrm{P}_{\text {app }}\right)$ of $\mathrm{Hg}$ in NCM460/HT29-MTX co-cultures exposed to $\mathrm{Hg}(\mathrm{II})$ or $\mathrm{MeHg}(0.5 \mathrm{mg} / \mathrm{L})$ and to the bacterial strains $\left(37^{\circ} \mathrm{C}, 2\right.$ h). BL17 is L. acidophilus ATCC4356 and BL23 is L. casei BL23.

\begin{tabular}{llll}
\hline Species & Treatment & $\mathbf{P}_{\text {app }}(\mathbf{c m} / \mathbf{s}) \times \mathbf{1 0}^{-\mathbf{6 a}}$ & Reduction in $\mathbf{P}_{\text {app }}$ \\
& & $7.05 \pm 0.83$ & NA $^{\mathrm{c}}$ \\
$\mathrm{Hg}(\mathrm{II})$ & w/o & $1.75 \pm 0.23$ & $75.2 \pm 3.2^{\mathrm{d}}$ \\
& BL17 (OD 0.3) & $91.9 \pm 1.6^{*}$ \\
& BL23 (OD 0.3) & $0.57 \pm 0.11$ & $\mathrm{NA}$ \\
$\mathrm{MeHg}$ & w/o & $5.88 \pm 0.65$ & - \\
& BL17 (OD 0.3) & $5.68 \pm 0.24$ & - \\
$\mathrm{MeHg}$ & BL23 (OD 0.3) & $5.39 \pm 0.49$ & $\mathrm{NA}$ \\
& w/o & $7.23 \pm 1.45$ & $19.1 \pm 8.7$ \\
& BL17 (OD 0.6) & $5.85 \pm 0.63$ & - \\
$\mathrm{MeHg}$ & BL23 (OD 0.6) & $7.80 \pm 1.19$ & $\mathrm{NA}$ \\
& w/o & $5.99 \pm 0.43$ & $30.6 \pm 4.5^{*}$ \\
& BL17 (OD 1.2) & $4.16 \pm 0.27$ & $20.1 \pm 4.2^{*}$ \\
\hline
\end{tabular}

${ }^{\text {a }}$ Means \pm standard deviations $(\mathrm{n}=4)$.

${ }^{\mathrm{b}}$ w/o; no bacteria added.

${ }^{\mathrm{c}}$ Not applicable.

${ }^{\mathrm{d}}$ Asterisks indicate statistically significant differences for $\mathrm{P}_{\text {app }}$ values in comparison to control experiments performed without bacteria $(\mathrm{p}<0.05)$.

${ }^{\mathrm{e}}$ Reduction in $\mathrm{P}_{\text {app }}$ below $10 \%$. 
Table 2. Mercury permeability from the bioaccessible fraction of swordfish.

Apparent permeability coefficients ( $\mathrm{P}_{\mathrm{app}}$ ) of $\mathrm{Hg}$ in NCM460/HT29-MTX co-cultures exposed or not to lactobacilli and to $\mathrm{Hg}$ present in the bioaccessible fraction of cooked swordfish $\left(37^{\circ} \mathrm{C}, 2 \mathrm{~h}\right)$. BL17 is L. acidophilus ATCC4356 and BL23 is L. casei BL23.

\begin{tabular}{lll}
\hline Treatment & $\mathbf{P}_{\text {app }}(\mathbf{c m} / \mathbf{s}) \times \mathbf{1 0}^{-6} \mathbf{a}$ & Reduction of $\mathbf{P}_{\text {app }}(\%)$ \\
\hline w/o $^{\mathrm{b}}$ & $1.59 \pm 0.29$ & \\
BL23 (OD 1.2) & $0.91 \pm 0.14$ & $42.3 \pm 8.9 *^{\mathrm{c}}$ \\
BL17 (OD 1.2) & $1.45 \pm 0.01$ & $8.5 \pm 5.2$ \\
\hline
\end{tabular}

${ }^{\text {a }}$ Means \pm standard deviations $(n=4)$.

${ }^{\mathrm{b}}$ w/o; no bacteria added.

${ }^{c}$ Asterisk indicates statistically significant differences for $\mathrm{P}_{\text {app }}$ values in comparison to control experiments performed without bacteria $(\mathrm{p}<0.05)$. 
Table 3. Relative bioavailability of $\mathrm{Hg}(\mathrm{II})$ and $\mathrm{MeHg}$ in exposed animals.

\begin{tabular}{lll}
\hline Strain & $\mathbf{F}(\%)^{\mathrm{a}} \mathbf{H g}(\mathbf{I I})$ & $\mathbf{F}(\%) \mathbf{M e H g}$ \\
\hline BL23 & $89 \pm 11$ & $61 \pm 14^{* \mathrm{~b}}$ \\
BL17 & $108 \pm 11$ & $58 \pm 17^{*}$ \\
\hline
\end{tabular}

${ }^{a}$ Values $(\mathrm{F} \%)$ are expressed as percentages with respect to animals treated with the mercurial forms only (mean $\pm \mathrm{SD}, \mathrm{n}=7$ ).

${ }^{\mathrm{b}}$ Asterisks indicate significant reductions compared to animals where no bacteria were administered $(\mathrm{p}<0.05)$. 


\section{Figure legends}

Figure 1. Mercury plasmatic levels in mice. AUC values for plasmatic $\mathrm{Hg}$ in mice treated with $\mathrm{Hg}(\mathrm{II})$ or $\mathrm{MeHg}$ with or without LAB. The data were obtained after a single $\mathrm{Hg}$ (II) or $\mathrm{MeHg}$ dose $(0.5 \mathrm{mg} / \mathrm{kg}$ body weight $)$ by oral gavage in the presence or absence of lactobacilli at the first day of $\mathrm{Hg}$ exposure. The values are expressed as $\mu \mathrm{g}$ $\mathrm{Hg} / \mathrm{mL} / \mathrm{min}(\mathrm{n}=7)$. Control indicates animals exposed to $\mathrm{Hg}$ without supplementation with lactobacilli. Asterisks show significant reductions compared to control animals ( $\mathrm{p}$ <0.05). BL17 is L. acidophilus ATCC4356 and BL23 is L. casei BL23.

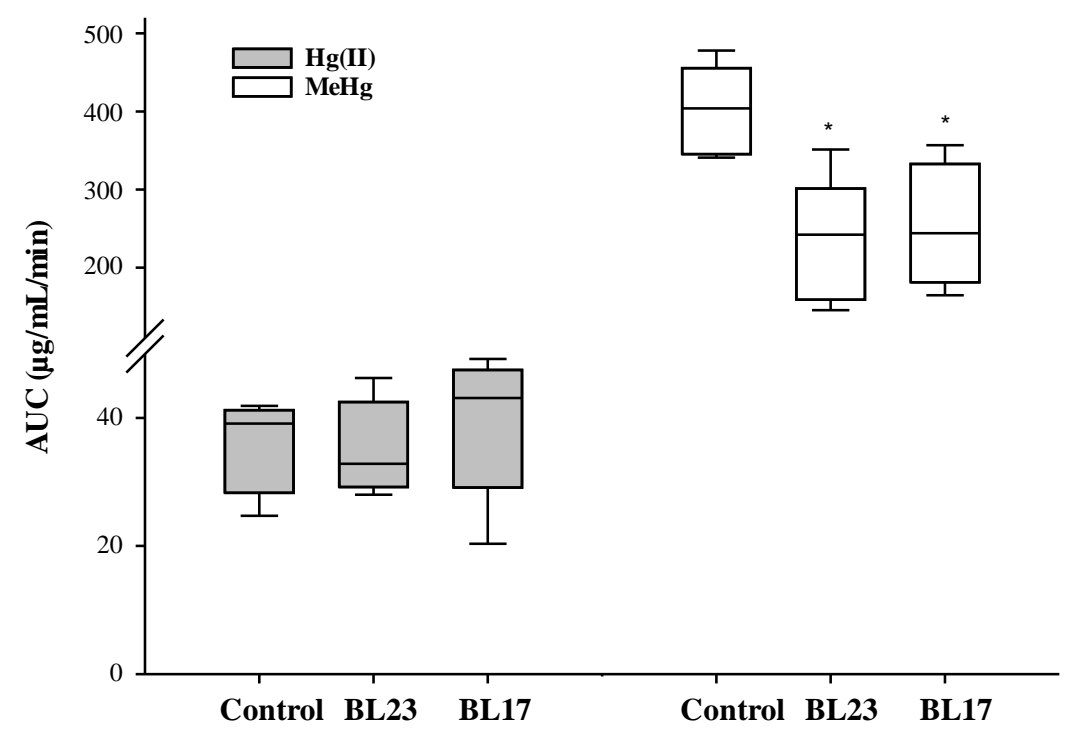


Figure 2. Mercury fecal excretion in mice. Concentrations of $\mathrm{Hg}$ in feces from animals treated with $\mathrm{Hg}$ (II) $(0.5 \mathrm{mg} / \mathrm{kg}$ body weight) (A) or $\mathrm{MeHg}(0.5 \mathrm{mg} / \mathrm{kg}$ body weight) (B) in the presence or absence of the two assayed lactobacilli. Values are expressed as $\mathrm{ng} \mathrm{Hg} / \mathrm{g}$ of feces $(\mathrm{n}=7)$. Asterisks show significant increases compared to animals not receiving bacteria ( $<$ 0.05). BL17 is L. acidophilus ATCC4356 and BL23 is L. casei BL23.
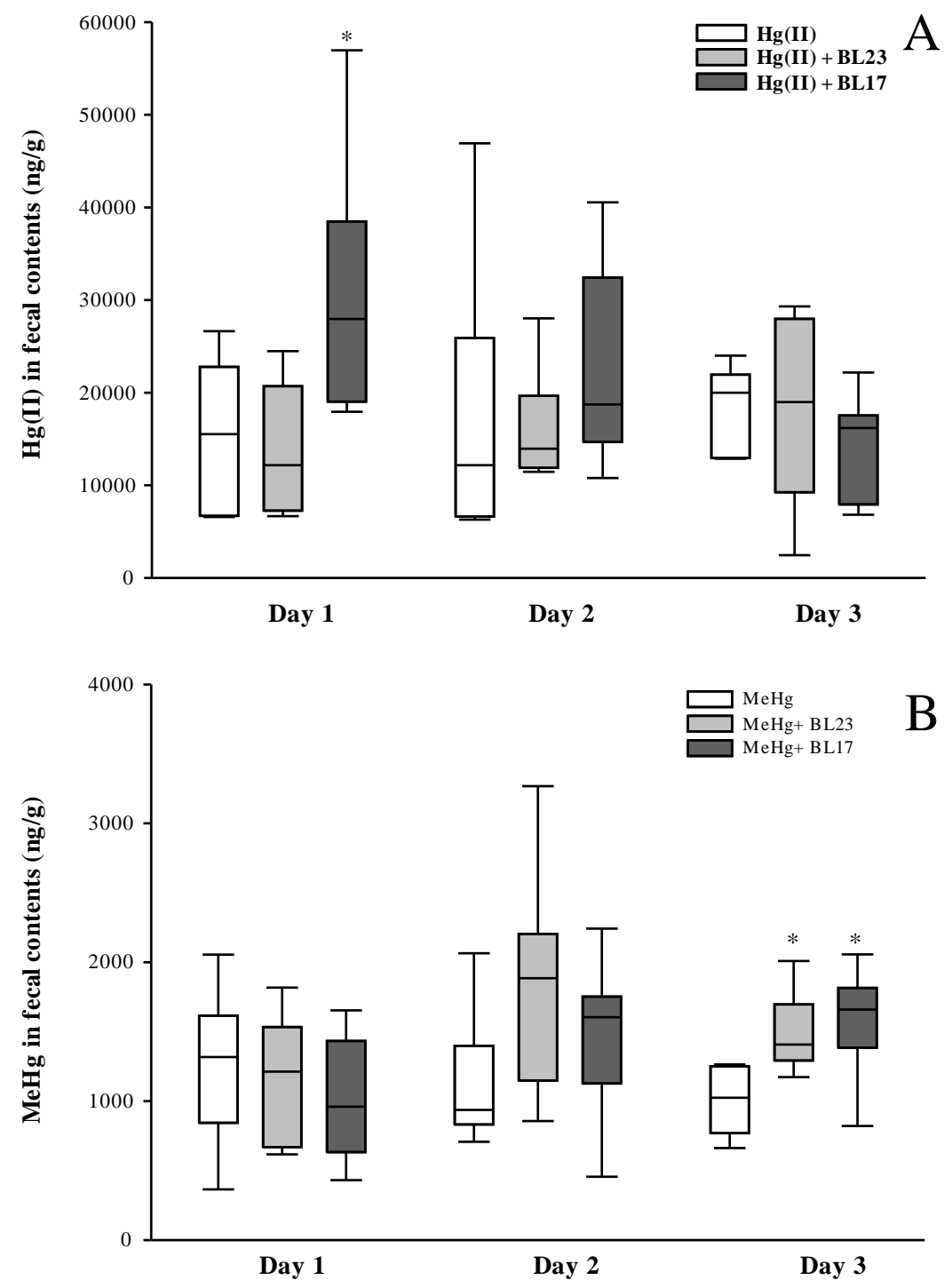
Figure 3. Tissular accumulation of mercury in mice. Mercury concentrations in liver (A) and kidney (B) of mice orally given $\mathrm{Hg}(\mathrm{II})(0.5 \mathrm{mg} / \mathrm{kg}$ body weight $)$ or $\mathrm{MeHg}(0.5$ $\mathrm{mg} / \mathrm{kg}$ body weight) with or without the assayed bacteria. Values are expressed as ng $\mathrm{Hg} / \mathrm{g}$ tissue (n=7). w/o; no bacteria were added. BL17 is L. acidophilus ATCC4356 and BL23 is L. casei BL23.
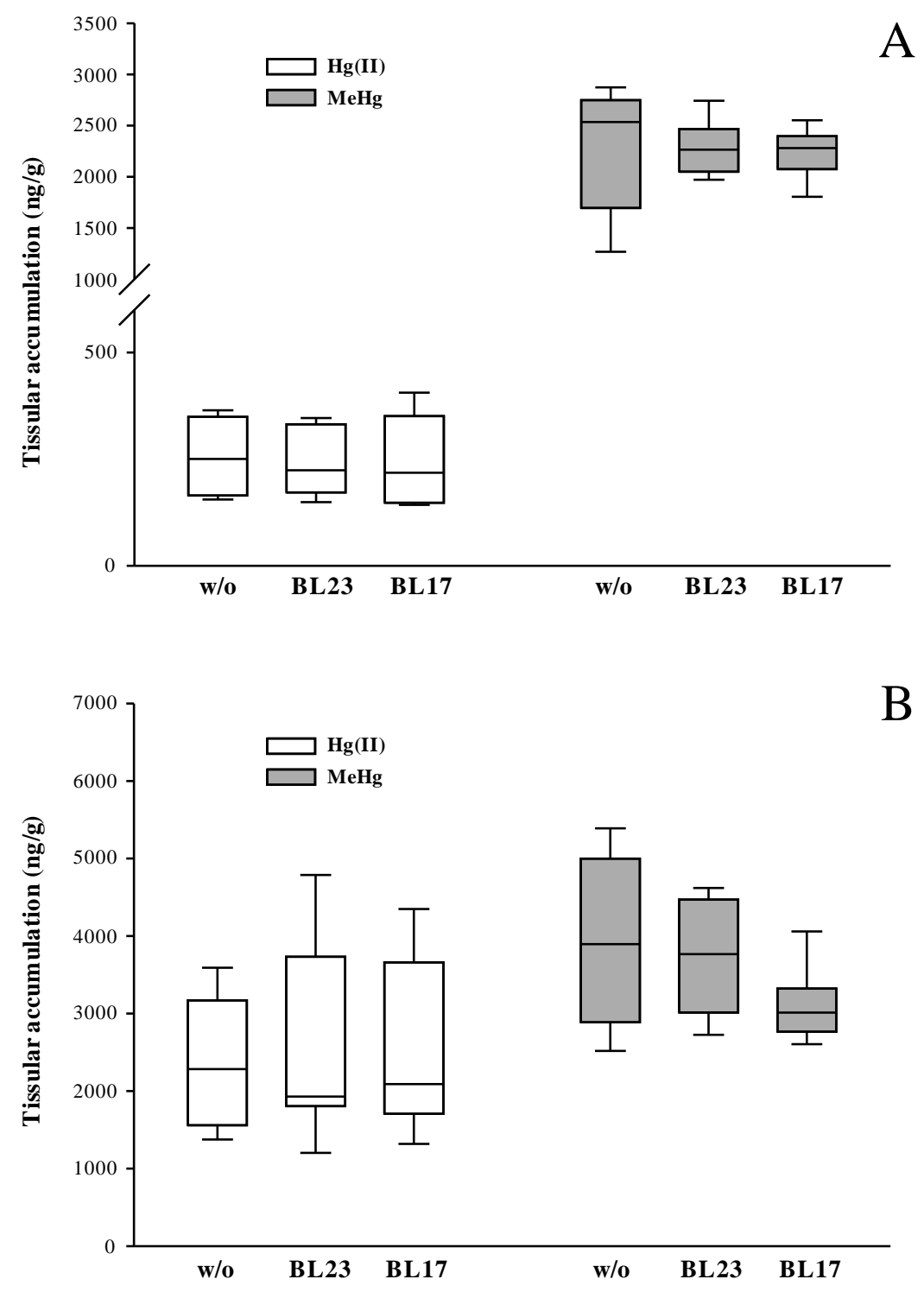


\section{REFERENCES}

Alcántara, C., Jadán-Piedra, C., Vélez, D., Devesa, V., Zúñiga, M., Monedero, V., 2017. Characterization of the binding capacity of mercurial species in Lactobacillus strains. J. Sci. Food Agric. 97, 5107-5113. https://doi.org/10.1002/jsfa.8388

Anderson, J.M., Van Itallie, C.M., 2009. Physiology and function of the tight junction. Cold Spring Harbor perspectives in biology 1, a002584. https://doi.org/10.1101/cshperspect.a002584

Ashe, K., 2012. Elevated mercury concentrations in humans of Madre de Dios, Peru. PLoS ONE 7, e33305. https://doi.org/10.1371/journal.pone.0033305

Bisanz, J.E., Enos, M.K., Mwanga, J.R., Changalucha, J., Burton, J.P., Gloor, G.B., Reid, G., 2014. Randomized open-label pilot study of the influence of probiotics and the gut microbiome on toxic metal levels in Tanzanian pregnant women and school children. MBio 5, e01580-01514. https://doi.org/10.1128/mBio.01580-14

BOE, 2013. Real Decreto 53/2013, de 1 de febrero, por el que se establecen las normas básicas aplicables para la protección de los animales utilizados en experimentación y otros fines científicos, incluyendo la docencia. BOE 34, 11370-11421.

Chiocchetti, G.M., Jadán-Piedra, C., Monedero, V., Zúñiga, M., Vélez, D., Devesa, V., 2018. Use of lactic acid bacteria and yeasts to reduce exposure to chemical food contaminants and toxicity. Crit. Rev. Food Sci. Nutr. 16, 1-12. https://doi.org/10.1080/10408398.2017.1421521

Daisley, B.A., Monachese, M., Trinder, M., Bisanz, J.E., Chmiel, J.A., Burton, J.P., Reid, G., 2018. Immobilization of cadmium and lead by Lactobacillus rhamnosus GR-1 mitigates apical-to-basolateral heavy metal translocation in a Caco-2 model of the intestinal epithelium. Gut Microbes 14, https://doi.org/10.1080/19490976.2018.1526581

EFSA, 2012. Scientific opinion on the risk for public health related to the presence of mercury and methylmercury in food. EFSA Journal 10, 2985. https://doi.org/10.2903/j.efsa.2012.2985

George, G.N., MacDonald, T.C., Korbas, M., Singh, S.P., Myers, G.J., Watson, G.E., O'Donoghue, J.L., Pickering, I.J., 2011. The chemical forms of mercury and selenium in whale skeletal muscle. Metallomics 3, 1232-1237. https://doi.org/10.1039/c1mt00077b

Guo, G., Yumvihoze, E., Poulain, A.J., Man Chan, H., 2018. Monomethylmercury degradation by the human gut microbiota is stimulated by protein amendments. J. Toxicol. Sci. 43, 717-725. https://doi.org/10.2131/jts.43.717

Halbach, S., 1990. Mercury compounds: lipophilicity and toxic effects on isolated myocardial tissue. Arch. Toxicol. 64, 315-319. https://doi.org/10.1007/bf01972992

Harris, H.H., Pickering, I.J., George, G.N., 2003. The chemical form of mercury in fish. Science 301, 1203-1203. https://doi.org/10.1126/science.1085941 
Hilgendorf, C., Spahn-Langguth, H., Regårdh, C.G., Lipka, E., Amidon, G.L., Langguth, P., 2000. Caco-2 versus Caco-2/HT29-MTX co-cultured cell lines: permeabilities via diffusion, inside- and outside-directed carrier-mediated transport. J. Pharm. Sci. 89, 63-75. https://doi.org/10.1002/(SICI)1520-6017(200001)89:1<63::AIDJPS7>3.0.CO;2-6

IARC, 1993. Mercury and mercury compounds. IARC Monographs on the evaluation of carcinogenic risks to humans 58, 239-345.

Jadán-Piedra, C., Alcántara, C., Monedero, V., Zúñiga, M., Vélez, D., Devesa, V., 2017. The use of lactic acid bacteria to reduce mercury bioaccessibility. Food Chem. 228, 158-166. https://doi.org/10.1016/j.foodchem.2017.01.157

Jadán-Piedra, C., Clemente, M.J., Devesa, V., Vélez, D., 2016. Influence of physiological gastrointestinal parameters on the bioaccessibility of mercury and selenium from swordfish. J. Agric. Food Chem. 64, 690-698. https://doi.org/10.1021/acs.jafc.5b05046

Jiang, X., Gu, S., Liu, D., Zhao, L., Xia, S., He, X., Chen, H., Ge, J., 2018. Lactobacillus brevis 23017 relieves mercury toxicity in the colon by modulation of oxidative stress and inflammation through the interplay of MAPK and NF- $\mathrm{\kappa B}$ signaling cascades. Front. Microbiol. 9. https://doi.org/10.3389/fmicb.2018.02425

Li, B., Jin, D., Yu, S., Etareri Evivie, S., Muhammad, Z., Huo, G., Liu, F., 2017. In vitro and in vivo evaluation of Lactobacillus delbrueckii subsp. bulgaricus KLDS1.0207 for the alleviative effect on lead toxicity. Nutrients 9, 845. https://doi.org/10.3390/nu9080845

Majlesi, M., Shekarforoush, S.S., Ghaisari, H.R., Nazifi, S., Sajedianfard, J., Eskandari, M.H., 2017. Effect of probiotic Bacillus coagulans and Lactobacillus plantarum on alleviation of mercury toxicity in rat. Probiotics Antimicrob. Proteins 9, 300-309. https://doi.org/10.1007/s12602-016-9250-X

Malm, O., 1998. Gold mining as a source of mercury exposure in the Brazilian Amazon. Environ. Res. 77, 73-78. https://doi.org/10.1006/enrs.1998.3828

Mazé, A., Böel, G., Zúñiga, M., Bourand, A., Loux, V., Yebra, M.J., Monedero, V., Correia, K., Jacques, N., Beaufils, S., Poncet, S., Joyet, P., Milohanic, E., Casaregola, S., Auffray, Y., Pérez-Martínez, G., Gibrat, J.F., Zagorec, M., Francke, C., Hartke, A., Deutscher, J., 2010. Complete genome sequence of the probiotic Lactobacillus casei strain BL23. J. Bacteriol. 192, 2647-2648. https://doi.org/10.1128/JB.00076-10

NRC, 2000. Toxicological effects of methylmercury. National Academy Press, Washington, D.C. https://doi.org/10.17226/9899

NTP, 1993. Toxicology and carcinogenesis studies of mercuric chloride in F344 rats and B6C3F1 mice (gavage studies). Natl. Toxicol. Program Tech. Rep. Ser. 408, 1-260.

Olivero-Verbel, J., Carranza-Lopez, L., Caballero-Gallardo, K., Ripoll-Arboleda, A., Muñoz-Sosa, D., 2016. Human exposure and risk assessment associated with mercury pollution in the Caqueta River, Colombian Amazon. Environ Sci. Pollut. Res. Int. 23, 20761-20771. https://doi.org/10.1007/s11356-016-7255-3 
Ramon, R., Murcia, M., Aguinagalde, X., Amurrio, A., Llop, S., Ibarluzea, J., Lertxundi, A., Alvarez-Pedrerol, M., Casas, M., Vioque, J., Sunyer, J., Tardon, A., Martinez-Arguelles, B., Ballester, F., 2011. Prenatal mercury exposure in a multicenter cohort study in Spain. Environ. Int. 37, 597-604. https://doi.org/10.1016/j.envint.2010.12.004

Sasser, L.B., Jarboe, G.E., Walter, B.K., Kelman, B.J., 1978. Absorption of mercury from ligated segments of the rat gastrointestinal tract. Proc. Soc. Exp. Biol. Med. 157, 57-60. https://doi.org/10.3181/00379727-157-39990

Tian, F., Zhai, Q., Zhao, J., Liu, X., Wang, G., Zhang, H., Zhang, H., Chen, W., 2012. Lactobacillus plantarum CCFM8661 alleviates lead toxicity in mice. Biol. Trace Elem. Res. 150, 264-271. https://doi.org/10.1007/s12011-012-9462-1

Torres-Escribano, S., Vélez, D., Montoro, R., 2010. Mercury and methylmercury bioaccessibility in swordfish. Food Addit. Contam. Part A 27, 327-337. https://doi.org/10.1080/19440040903365272

Ulluwishewa, D., Anderson, R.C., McNabb, W.C., Moughan, P.J., Wells, J.M., Roy, N.C., 2011. Regulation of tight junction permeability by intestinal bacteria and dietary components. J. Nutr. 141, 769-776. https://doi.org/10.3945/jn.110.135657

Vázquez, M., Devesa, V., Vélez, D., 2015. Characterization of the intestinal absorption of inorganic mercury in Caco-2 cells. Toxicol. In Vitro 29, 93-102. https://doi.org/10.1016/j.tiv.2014.09.013

Vázquez, M., Vélez, D., Devesa, V., 2014. In vitro characterization of the intestinal absorption of methylmercury using a Caco-2 cell model. Chem. Res. Toxicol. 27, 254264. https://doi.org/10.1021/tx4003758

Yi, Y.-J., Lim, J.-M., Gu, S., Lee, W.-K., Oh, E., Lee, S.-M., Oh, B.-T., 2017. Potential use of lactic acid bacteria Leuconostoc mesenteroides as a probiotic for the removal of $\mathrm{Pb}$ (II) toxicity. J. Microbiol. 55, 296-303. https://doi.org/10.1007/s12275-017-6642-X

Zhai, Q., Tian, F., Zhao, J., Zhang, H., Narbad, A., Chen, W., 2016. Oral administration of probiotics inhibits absorption of the heavy metal cadmium by protecting the intestinal barrier. Appl. Environ. Microbiol. 82, 4429-4440. https://doi.org/10.1128/AEM.00695$\underline{16}$

Zhai, Q., Wang, G., Zhao, J., Liu, X., Tian, F., Zhang, H., Chen, W., 2013. Protective effects of Lactobacillus plantarum CCFM8610 against acute cadmium toxicity in mice. Appl. Environ. Microbiol. 79, 1508-1515. https://doi.org/10.1128/AEM.03417-12

Zhai, Q., Xiao, Y., Tian, F., Wang, G., Zhao, J., Liu, X., Chen, Y.Q., Zhang, H., Chen, W., 2015. Protective effects of lactic acid bacteria-fermented soymilk against chronic cadmium toxicity in mice. RSC Adv. 5, 4648-4658. https://doi.org/10.1039/C4RA12865F 